\title{
Potential of retinoic acid derivatives for the treatment of corticotroph pituitary adenomas
}

\author{
Marta Labeur • Marcelo Paez-Pereda • Eduardo Arzt • \\ Günter K. Stalla
}

Published online: 7 July 2008

(C) The Author(s) 2008

\begin{abstract}
Cushing's disease is a severe clinical condition caused by hypersecretion of corticosteroids due to excessive ACTH secretion from a pituitary adenoma. This complex endocrine disorder still represents a major challenge for the physician in terms of efficient treatment. In the last years there was only little progress in elucidating the molecular mechanisms responsible for the constitutive and autonomous ACTH secretion of pituitary corticotrophinomas. As a consequence, no effective drug therapy is currently available, particularly if surgical excision is not successful. In the present article we examine recent studies that have investigated the therapeutic potential of retinoic acid receptors as nuclear receptor targets for the treatment of Cushing's disease. Retinoic acid is an efficient drug used for the treatment of different types of cancers and it proved to act in animal models of Cushing's disease. The efficiency of this treatment in patients with this disorder still needs to be tested in clinical trials.
\end{abstract}

M. Labeur · G. K. Stalla $(\bowtie)$

Max Planck Institute of Psychiatry,

Munich, Germany

e-mail: stalla@mpipsykl.mpg.de

M. Labeur

e-mail: labeur@mpipsykl.mpg.de

M. Paez-Pereda

Affectis Pharmaceuticals,

Munich, Germany

e-mail: paez-pereda@affectis.com

E. Arzt

Lab. de Fisiología y Biología Molecular,

FCEN, UBA and CONICET,

Buenos Aires, Argentina

e-mail: earzt@fbmc.fcen.uba.ar
Keywords Cushing's disease $\cdot$ Retinoic acid . Retinoic acid receptors · Corticotrophinomas . Pituitary adenomas

\section{Pituitary adenomas and Cushing's disease}

Pituitary tumors are common neoplasms, reported to account for $10-15 \%$ of all intracranial tumors, being therefore the second most common neoplasm after meningeomas [1]. The prevalence is $300 / 1,000,000$ inhabitants. Pituitary adenomas are composed of adenohypophysial cells and arise usually in the sella turcica. Their hormonal activity is usually reflective of the cytodifferentiation. The clinical picture can be very variable, many tumors are silent and not frequently diagnosed, while others may be life-threatening. Little is known about the precise environmental and genetic factors leading to their development, so preventive measures are unavailable. About two-thirds of pituitary tumors express and secrete pituitary hormones leading to various endocrine syndromes. One of the most severe is the Cushing's syndrome, which results from chronic exposure to glucocorticoids in the blood from a variety of causes, including primary pituitary adenoma (known as Cushing's disease), primary adrenal hyperplasia or neoplasia and ectopic ACTH production (e.g., from a small cell lung cancer) [2-6]. It is characterized by a typical abnormal fat deposition around the neck, skin thinning, adrenal hyperplasia osteoporosis, insulin resistance, dyslipidemia, myopathy, amenorrhea and hypertension. Fatigue, irritation, anxiety and depression are also common clinical features in these patients $[2,3,5,6]$. At the moment, there is no effective pharmacological therapy to control ACTH over-secretion by pituitary tumors [2, 3, 5-8]. In the absence of efficient medical therapy, transsphenoidal 
adenomectomy is still the treatment of choice for ACTHsecreting tumors [7, 8]. However, some difficulties prevent this approach in many patients. In the first place, ACTHsecreting pituitary adenomas are usually very small, although they secrete abundant amounts of ACTH. Their small size and structure makes it difficult to localize them with the current imaging methods. This fact leads to a higher rate of recurrence in these tumors due to partial resection. In some cases, total hypophysectomy is needed to ensure the resection of the tumor. In these cases a side effect of surgery is the insufficiency of pituitary hormones. These patients require constant monitoring of the endocrine axis and hormone replacement therapy. Beside that, surgery is associated, with significant post-operative morbidities $[9$, 10]. In case of adrenal tumor or ectopic ACTH secretion, surgical removal of the tumor is mandatory, when possible. Future studies are needed, on one hand to provide tools for a better prediction of tumor behaviour and on the other to provide novel targets for pharmaceutical therapy.

Only very recently, molecular biology studies have provided novel potential targets for therapy. The role and the ability of nuclear receptors such as retinoic acid receptors to regulate normal and pathological pituitary tumor hormone secretion and cell growth will be discussed.

\section{Retinoic acid receptors}

The retinoids are natural and synthetic derivatives of vitamin A that regulate diverse cellular growth and differentiation programmes, survival and death [11]. Retinoids activate the transcription of target genes through interaction with the nuclear transcription factors of the retinoic acid receptor $(\operatorname{RAR} \alpha, \operatorname{RAR} \beta, \operatorname{RAR} \gamma)$ and retinoid $\mathrm{X}$ receptor $(\mathrm{RXR} \alpha$, $\operatorname{RAR} \beta, \operatorname{RXR} \gamma$ ) families [12-14]. The $\alpha, \beta$ and $\gamma$ isoforms are each expressed from the three isotypic genes $(\alpha, \beta$ and $\gamma)$, expressing by differential promoter usage and splicing $[15,16]$. At the molecular level, RARs and RXRs form heterodimers that respond to RAR ligands. RXRs also heterodimerize with other nuclear receptors, some of which become transcriptionally active in the sole presence of an RXR selective ligand (rexinoid) [11]. However rexinoid agonists superactivate transcription induced by RAR-RXR in the presence of RAR agonists. In the absence of ligand, retinoid receptors bind specific retinoic-acid response elements on target genes and recruit nuclear co-repressors, such as NCOR (nuclear receptor co-repressor) and SMRT (silencing mediator of RAR and thyroid hormone receptor). Retinoid binding to these receptors leads to release of corepressors and recruitment of transcriptional co-activators to regulate a diverse range of genes involved in transcrip- tional and apoptosis regulation, proliferation and protein modification [17].

Retinoic acid receptors are important drug targets for cancer therapy and prevention [18, 19]. The activities mediated by the retinoid receptors encompass, for example, the induction of cell-cycle regulators (cyclin-dependent kinase inhibitor $\mathrm{p} 21^{\mathrm{WAF} 1 / \mathrm{CIP} 1}$ ), the repression of AP1 (the Fos-Jun proto-oncogene product), and the induction of the tumor-cell-selective apoptosis ligand TRAIL [19, 20]. Strong evidence indicates that the RA-inducible RAR $\beta$, acts as a tumor suppressor [11,20].

At pharmacological dosages, retinoids are used to treat patients with acute promyelocytic leukaemia (APL), as well as other malignant, pre-malignant and non-malignant disorders. The efficacy of retinoids in suppressing tumor development has been demonstrated in animal carcinogenesis models [21].

All-trans-retinoic acid (ATRA) and 9-cis retinoic acid (9cis-RA) are the most biologically active retinoic acid isomers, whereas 13-cis-retinoic acid (13-cis-RA) is considered less active and may require isomerization to ATRA in order to exert biologic function [22, 23]. Differences in ATRA and 13-cis-RA metabolism and pharmacokinetics have been reported in cancer patients [24-30]. ATRA is rapidly cleared from plasma (plasma half-life $<1 \mathrm{~h}$ ) and induces its own metabolism, which is a significant therapeutic obstacle. In contrast, 13-cis-RA is slowly cleared from plasma (plasma half-life $>13 \mathrm{~h}$ ) and does not induce its own metabolism. Different strategies to overcome selfinduced ATRA metabolism and thus improve therapeutic efficacy were proposed in emphysema patients [31]. The authors concluded that intermittent therapy with high-dose ATRA produced the greatest ATRA exposure, but alternative approaches for limiting self-induced ATRA catabolism should be sought. A recent study on pharmacokinetics of ATRA in adults and children with acute promyelocytic leukaemia shows that although its bioavailability is similar in both age groups the incidence of CNS toxicity due to ATRA is higher in children than in adults [32]. Unfortunately, a key limitation of retinoid therapy is that concentrations required for anticancer actions cause several side effects, including teratogenicity, mucocutaneous toxicity, defects in liver function, conjunctivitis, mucositis and severe photosensitivity. Rexinoids are, in general, much less toxic [33].

The search for isotype-selective modulators [15, 34-36] is pursued to first, reduce side effects associated with current retinoid therapy; second, elicit more specific biological responses, because the tissue distribution of retinoid receptors isotypes is not uniform, third, better define the physiological role of each retinoid receptor isotype in the 
Table 1 Retinoids in clinical trials or approved for therapy—adapted from Altucci et al. [11]

\begin{tabular}{ll}
\hline Name (trade name/company) & Phase/indication \\
\hline Tretinoin & Launched: acne, APL, warts \\
& Phase II: brain, breast, renal cancers, SCLC, Kaposi's sarcoma, Wilms' tumor, malignant melanoma \\
Isotretinoin & Launched: acne \\
& Phase III: isotretinoin plus IFN $\alpha$ plus vitamin E in III or stage IV head and neck cancer \\
& Phase III: high-grade glioma \\
& Phase III: combination therapy with isotretinoin in neuroblastoma \\
& Phase II:T-cell malignancies \\
& Phase II: IFN $\alpha$ plus isotretinoin plus paclitaxel recurrent SCLC \\
& Phase II combination chemotherapy in juvenile myelomonocytic leukaemia \\
& Launched: acne, psoriasis, photodamage \\
Tazarotene & Phase II: emphysema \\
R667 &
\end{tabular}

Abbreviations: APL, acute promyelocytic leukaemia; IFN $\alpha$, interferon- $\alpha$; SCLC, small-cell lung cancer

control of certain biological phenomena such as proliferation, differentiation and apoptosis [15].

A summary on retinoids and rexinoids that are of clinical importance or being evaluated in clinical trials is provided in Tables 1 and 2 [11].

\section{Signaling pathways and transcriptional regulation of ACTH biosynthesis}

$\mathrm{CRH}$ increases pro-opiomelanocortin (POMC) gene expression and stimulates adrenocorticotrophin (ACTH) synthesis and secretion [37] through the interaction with the CRH receptor type 1 (CRHR1) localized in corticotrophs (Fig. 1). Activation of the CRHR1 results in Gs-mediated stimulation of adenylate cyclase, leading to increased levels of intracellular cyclic AMP (cAMP), and the activation of protein kinase A (PKA) [38], which stimulates different transcription factors [39-41]. Two Nur DNA binding sites have been identified on the POMC promoter. The proximal binding sequence named Nur77-binding response element (NBRE) binds Nur 77 or Nurr1 monomers. The distal Nur response element (NurRE), constituted of two everted NBRE related sites, binds Nur77 homodimers or Nur77/ Nurr1 heterodimers and plays a dominant role in mediating stimulation by CRH [42-44]. Upon stimulation with CRH, the ERK pathway is activated in corticotrophs and this activation is instrumental in the regulation of Nur77/Nurr 1 [38]. The expression of these nuclear receptors in ACTHsecreting cells and also in the hypothalamus and adrenal glands might make them useful therapeutic targets for drugs which may aim to modulate the activity of the HPA axis.

$\mathrm{CRH}$ also induces transcriptional activity of activating protein 1 (AP-1) and cAMP response element binding protein (CREB), which have been proposed to be involved in POMC transcription at the level of the AP-1 site located in the first exon [40, 45]. Other hormones and neuropeptides [e.g. arginine vasopressin (AVP)] also modify POMC transcription by acting on the second messengers, cAMP and $\mathrm{Ca}^{++}$(the calcium/calmodulin pathway). Upon glucocorticoid receptor binding, glucocorticoids exert their negative effect by binding on the glucocorticoid responding element (GRE) situated on the POMC promoter and thus, inhibiting ACTH synthesis.

\section{Retinoic acid and Cushing's disease}

4.1 In vitro data: AtT-20 pituitary corticotroph tumor cells and human corticotrophinomas

Consistent with previous studies of retinoid action in other tumor models, in AtT-20 pituitary ACTH -secreting tumor cells, retinoic acid inhibits ACTH secretion in vitro by

Table 2 Rexinoids in clinical trials or approved for therapy - adapted from Altucci et al [11]

\begin{tabular}{ll}
\hline $\begin{array}{l}\text { Name (trade name/ } \\
\text { company) }\end{array}$ & Phase/indication \\
\hline Bexarotene & Launched: cutaneous T-cell lymphoma \\
& Phase III: NSCLC \\
& Phase II (oral): breast, colorectal, prostate, \\
& psoriasis, renal \\
& Phase II (topical): actinic keratosis, alopecia \\
& areata, atopic dermatitis, Kaposi's sarcoma, \\
& mycosis fungoides, psoriasis \\
& Preclinical \\
\hline
\end{tabular}

NSCLC Non-small-cell lung cancer 
Fig. 1 Regulation of $\mathrm{ACTH}$ biosynthesis. CRH binds to its seven transmembrane receptor, induces cAMP and intracellular calcium, and subsequently activates several transcription factors including Nur, CREB, c-fos and JunB, which activate the POMC promoter leading to $\mathrm{ACTH}$ biosynthesis

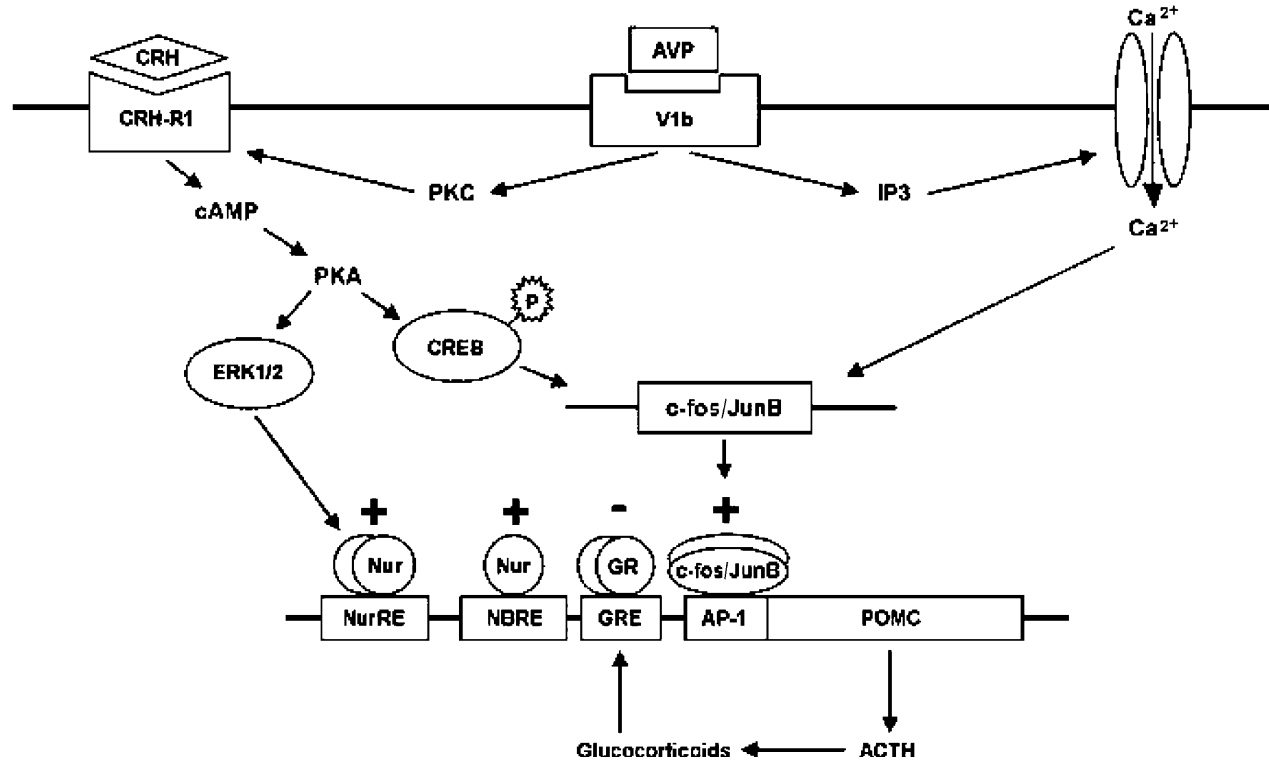

inhibiting the transcriptional activity of the transcription factors AP1 and Nur on the POMC gene, which encodes ACTH [46]. However, this inhibitory action of retinoic acid seems to be restricted to ACTH-secreting tumor cells, since, in rat normal pituitary cells, neither $\mathrm{ACTH}$, prolactin nor growth hormone are affected by the treatment, demonstrating a specific effect on tumor cells probably related to the distinct differentiation degree of normal cells versus tumor cells. COUP-TF1 (chicken ovalbumin upstream promotertranscription factor 1), an orphan receptor that belongs to the steroid/thyroid hormone receptor superfamily, with a hypothetical role in the differentiation of ACTH-secreting cells [46-48],was described to inhibit the retinoic acid response pathways [48-50]. In this direction, in normal ACTH-secreting cells - the corticotrophs-COUP-TF1 was expressed and cells remained unaffected by the retinoic acid treatment. By contrast, in ACTH-secreting tumors, no expression of COUP-TF1 was observed. Moreover, the retinoic acid effects were blocked in AtT-20 cells transfected with the COUP-TF1 expression vector.

Treatment of human corticotrophinomas in primary culture with $10 \mathrm{nM}$ retinoic acid resulted in the inhibition of the ACTH production by six out of eight tumors. All tumors tested responded to retinoic acid when a higher doses $(100 \mathrm{nM})$ was used. ACTH inhibition was also observed in tumor cells with lung origin, demonstrating that the $\mathrm{ACTH}$ biosynthesis is affected by retinoic acid in different tumor types. Furthermore retinoic acid inhibits cell proliferation and induces apoptosis in ACTH-secreting tumor cells [46]. AP-1 and Nur77 were described to mediate the antiproliferative effects of retinoic acid $[47,51]$. Nevertheless, due to the fact that retinoic acid has pleiotropic effects, it cannot be excluded the possibility that other pathways independent of AP-1 or Nur77/Nurr1 could contribute to this effects.
Moreover, retinoic acid induces caspase-3 activity, a key mediator of the proteolytic cascade leading to apoptosis, and reduces cell viability. In adrenal cortex cells, retinoic acid inhibited the forskolin induced - corticosterone production and - cell proliferation [46].

Regarding to other pituitary adenomas, retinoic acid has been shown to stimulate growth hormone in vitro in the lacto-somatotropic tumor cell line $\mathrm{GH} 3$ and in human somatotropic adenoma cells $[52,53]$. Therefore, retinoic acid would not represent a possibility for the treatment of growth hormone secreting tumors.

\subsection{In vivo data: experimental Cushing's disease in nude mice}

The in vivo retinoic acid effects paralleled the in vitro effects [46]. When athymic nude mice were inoculated with corticotroph tumor cells, large subcutaneous corticotroph tumors were developed, whereas no tumors were observed in mice injected with retinoic acid treated cells, indicating that the anti-proliferative effects of retinoic acid are also effective in vivo. Thus, retinoic-acid inhibition of proliferation and apoptosis induction combined to reduce tumor mass. Moreover, administration of retinoic acid to mice that already had experimental ACTH-secreting tumors, resulted in the inhibition of tumor growth. Plasma levels of ACTH and cortisol were reduced in retinoic acid treated mice, compared with vehicle. These hormonal inhibition together with the reduction of tumor mass, resulted in the reversion of adrenal hyperplasia and skin atrophy, both characteristic symptoms of Cushing's syndrome [46].

Thus, the retinoic acid effects combine in vivo to reverse the endocrine alterations and symptoms observed in experimental Cushing's syndrome [46]. 


\subsection{In vivo data: Cushing's disease in dogs}

Cushing's disease is common in dogs and it is almost always caused by an ACTH secreting pituitary tumor. Ketoconazole is an established treatment for Cushing's disease, both in the human and in dogs [54], which operates by interfering with steroid biosynthetic pathways. Although ketoconazole controls the excessive glucocorticoid secretion in some patients, it does not inhibit tumor growth. In vitro, ketoconazole was shown, to inhibit the cAMP synthesis, necessary for ACTH stimulation. However, other pituitary hormones also require cAMP signalling for their normal biosynthesis, therefore ketaconazole would not specifically inhibit ACTH [55-57] but other hormones as well. As in humans, no effective medical therapy for the treatment of dogs with Cushing's disease is currently available. The up to date established treatments for dogs with Cushing's disease have limited efficacy and serious side effects.

A randomised study using retinoic acid in dogs with Cushing's disease was performed [58]. Dogs were treated with retinoic acid $(n=22 \mathrm{dogs})$ or ketoconazole $(n=20 \mathrm{dogs})$ for a period of 180 days. Clinical signs, plasma ACTH and $\alpha-\mathrm{MSH}$, the cortisol/creatinine $(\mathrm{RC} / \mathrm{C})$ urine ratio and pituitary MRI were assessed and compared at different time points [58]. In dogs, two convertase enzymes are involved in processing the POMC gene products, one active in anterior pituitary cells secreting $\mathrm{ACTH}$, whereas the other is located in the intermediate-lobe cells secreting $\alpha-\mathrm{MSH}$ [59]. Therefore not only ACTH but also $\alpha$-MSH was assessed. In the ketoconazole group there were no significant changes in ACTH or $\alpha$-MSH at any time studied. In contrast, there was a significant reduction in plasma $\mathrm{ACTH}$ and $\alpha-\mathrm{MSH}$ in the retinoic acid treated dogs along the time. The differences between the treatment groups were statistically significant at 120 and 180 days for ACTH and 120 days for $\alpha-\mathrm{MSH}$. Thus, the ACTH and $\alpha-\mathrm{MSH}$ reduction suggests that retinoic acid acts on both, the anterior and the intermediate pituitary lobe probably at the POMC transcription level. The $\mathrm{RC} / \mathrm{C}$ ratio decreased significantly in both groups from 120 days on. This reduction was significantly different between the groups at 180 days. Pituitary adenoma size was also significantly reduced at the end of retinoic acid treatment. Nevertheless, no reduction was observed in the ketoconazole group.

The survival time after initiation of treatment was significantly longer in the retinoid acid group compared with the ketoconazole group. Moreover, in the ketoconazole group, more than $50 \%$ of the animals died before completing the treatment, usually from complications of the glucocorticoid excess [58].

Retinoic acid induced an improvement in almost all the clinical signs monitored (return of oestrus, food intake, skin appearance and hair loss). Weight was the only parameter studied that did not show significant differences between the groups. Nevertheless, there was a decline in mean body weight in both groups.

Thus, retinoic acid treatment controls ACTH and cortisol hyperactivity, and tumor size in dogs with $\mathrm{ACTH}$ secreting tumors leading to resolution of the clinical phenotype. No adverse events with retinoic acid were recorded, except for one case of footpad hyperkeratosis. Moreover, there was no evidence of hepatotoxicity during or after the study in terms of hepatic enzyme abnormalities. Based on these data, the dose of retinoic acid used was not only effective but also appeared to be safe. Because of the similarity of canine to many human diseases, it has been suggested that the dog may help to bridge the gap between preclinical drug studies and the effects of the same drug in humans [60]. This study highlights the possibility of using retinoic acid as a novel therapy in the treatment of ACTH-secreting tumors in humans with Cushing's disease [58]. It is important to note that according to the "U.S. Food and Drug Administration guidelines" for extrapolating animal doses to human equivalent doses considering weight and skin surface, the retinoic acid doses used in the above described mice [46] and dogs [58] studies are within the range of doses that could be used in humans.

\subsection{BMP-4 involvement in the retinoic acid inhibitory action}

During pituitary organogenesis, bone morphogenic protein 2 and 4 (BMP2 and 4), two members of the TGF- $\beta$ superfamily, have been shown to play an important paracrine/autocrine role during the initial steps of the anterior pituitary development [61]. BMP-4 is expressed in the corticotrophs of human normal pituitary and its expression is reduced in corticotrophinomas obtained from Cushing's patients compared to the normal pituitary. BMP-4 treatment of AtT-20 mouse corticotrophinoma cells has an inhibitory effect on ACTH secretion and cell proliferation. AtT-20 cells stably transfected with a dominant negative form of the BMP-4 signal cotransducer Smad-4 or the BMP-4 inhibitor noggin have increased tumorigenicity in nude mice, demonstrating that BMP-4 has an inhibitory role on corticotroph tumorigenesis in-vivo. Retinoic acid induces both BMP-4 transcription and expression and its antiproliferative action is blocked in Smad-4 dominant negative and noggin transfected Att-20 cells that do not respond to BMP4. Therefore, BMP-4 is induced by and mediates some of the retinoic acid effects [62].

\section{Conclusion}

At present, there is no effective pharmacological therapy that has been clinically tested to control ACTH-oversecretion 
by pituitary tumors. Recent advances in elucidating the function of nuclear receptors have resulted in the development of novel approaches. The potential importance of retinoic acid receptors in the treatment of Cushing's disease was tested in different animal models with ACTH secreting pituitary cells. Thus, the antiproliferative action and the ACTH and corticosterone inhibition induced by retinoic acid in vitro were confirmed in vivo in mice with experimental ACTH secreting tumors and in dogs with Cushing's disease.

\section{Key unanswered questions}

Retinoic acid might represent a potential therapeutic option to inhibit ACTH production, as well as tumor growth in Cushing's disease. However, the efficiency of these treatments in patients with Cushing's syndrome still needs to be tested in clinical trials.

Open Access This article is distributed under the terms of the Creative Commons Attribution Noncommercial License which permits any noncommercial use, distribution, and reproduction in any medium, provided the original author(s) and source are credited.

\section{References}

1. Ambrosi B, Faglia G. Epidemiology of pituitary tumors I. In: Faglia $\mathrm{G}$ et al, editor. Pituitary adenomas: new trends in basic and clinical research. Amsterdam New York: Elsevier; 1991. p. 159-68.

2. Orth DN. Cushing's syndrome. N Engl J Med. 1995;332:791803. doi:10.1056/NEJM199503233321207.

3. Dahia PL, Grossman AB. The molecular pathogenesis of corticotroph tumors. Endocr Rev. 1999;20:136-55. doi:10.1210/er.20. 2.136 .

4. Wajchenberg BL, Bergaria Pereira MA, Medonca BB, Latronico AC, Campos CP, Alves VA, Zerbini MC, Liberman B, Carlos GG, Kirschner MA. Adrenocortical carcinoma: clinical and laboratory observations. Cancer. 2000;88:711-36. doi:10.1002/(SICI)10970142(20000215)88:4<711::AID-CNCR1>3.0.CO;2-W.

5. Wajchenberg BL, Mendonca BB, Liberman B, Pereira MA, Carneiro PC, Wakamatsu A, et al. Ectopic adrenocorticotropic hormone syndrome. Endocr Rev. 1994;15:752-87. doi:10.1210/er.15.6.752.

6. Boscaro M, Barzon L, Fallo F, Sonino N. Cushing's syndrome. Lancet. 2001;357:783-91. doi:10.1016/S0140-6736(00)04172-6.

7. Miller JW, Crapo L. The medical treatment of Cushing's syndrome. Endocr Rev. 1993;14:443-58. doi:10.1210/er.14.4.443.

8. Colao A, Di SA, Marzullo P, Di SC, Cerbone G, Landi ML, et al. New medical approaches in pituitary adenomas. Horm Res. 2000;53(Suppl 3):76-87. doi:10.1159/000023539.

9. Melmed S. Mechanisms for pituitary tumorigenesis: the plastic pituitary. J Clin Invest. 2003;112:1603-18.

10. Heaney AP, Melmed S. Molecular targets in pituitary tumours. Nat Rev Cancer. 2004;4:285-95. doi:10.1038/nrc1320.

11. Altucci L, Leibowitz MD, Ogilvie KM, de Lera AR, Gronemeyer H. RAR and RXR modulation in cancer and metabolic disease. Nat Rev Drug Discov. 2007;6:793-810. doi:10.1038/nrd2397.
12. Chambon P. A decade of molecular biology of retinoic acid receptors. FASEB J. 1996;10:940-54.

13. Zhang XK, Hoffmann B, Tran PB, Graupner G, Pfahl M. Retinoid $\mathrm{X}$ receptor is an auxiliary protein for thyroid hormone and retinoic acid receptors. Nature. 1992;355:441-6. doi:10.1038/355441a0.

14. Gudas LJ, Sporn MB, Roberts AB. The retinoids biology, chemistry and medicine. In: Sporn MB, Roberts AG, and Goodman DS, editors. New York, Raven; 1994. pp 443-520.

15. de Lera AR, Bourguet W, Altucci L, Gronemeyer H. Design of selective nuclear receptor modulators: RAR and RXR as a case study. Nat Rev Drug Discov. 2007;6:811-20. doi:10.1038/nrd2398.

16. Laudet V, Gronemeyer H. The nuclear receptor facts book. San Diego: Academic Press; 2002.

17. Pitha-Rowe I, Petty WJ, Kitareewan S, Dmitrovsky E. Retinoid target genes in acute promyelocytic leukemia. Leukemia. 2003; 17:1723-30. doi:10.1038/sj.leu.2403065.

18. Lippman SM, Lotan R. Advances in the development of retinoids as chemopreventive agents. J Nutr. 2000;130:479S-82S.

19. Altucci L, Gronemeyer H. The promise of retinoids to fight against cancer. Nat Rev Cancer. 2001;1:181-93. doi:10.1038/35106036.

20. Clarke N, Germain P, Altucci L, Gronemeyer H. Retinoids: potential in cancer prevention and therapy. Expert Rev Mol Med. 2004;6:1-23. doi:10.1017/S1462399404008488.

21. Kurie JM. The biologic basis for the use of retinoids in cancer prevention and treatment. Curr Opin Oncol. 1999;11:497-502. doi:10.1097/00001622-199911000-00011.

22. Levin AA. Receptors as tools for understanding the toxicity of retinoids. Toxicol Lett. 1995;82-83:91-7. doi:10.1016/0378-4274 (95)03546-X.

23. Kim YW, Sharma RP, Li JK. Characterization of heterologously expressed recombinant retinoic acid receptors with natural or synthetic retinoids. J Biochem Toxicol. 1994;9:225-34. doi:10.1002/jbt.2570090502.

24. Muindi JR, Frankel SR, Huselton C, DeGrazia F, Garland WA, Young $\mathrm{CW}$, et al. Clinical pharmacology of oral all-trans retinoic acid in patients with acute promyelocytic leukemia. Cancer Res. 1992;52:2138-42.

25. Smith MA, Adamson PC, Balis FM, Feusner J, Aronson L, Murphy RF, et al. Phase I and pharmacokinetic evaluation of alltrans-retinoic acid in pediatric patients with cancer. J Clin Oncol. 1992;10:1666-73.

26. Trump DL, Smith DC, Stiff D, Adedoyin A, Day R, Bahnson RR, et al. A phase II trial of all-trans-retinoic acid in hormonerefractory prostate cancer: a clinical trial with detailed pharmacokinetic analysis. Cancer Chemother Pharmacol. 1997;39:349-56. doi:10.1007/s002800050582.

27. Conley BA, Egorin MJ, Sridhara R, Finley R, Hemady R, Wu S, et al. Phase I clinical trial of all-trans-retinoic acid with correlation of its pharmacokinetics and pharmacodynamics. Cancer Chemother Pharmacol. 1997;39:291-9. doi:10.1007/s002800050575.

28. Muindi J, Frankel SR, Miller WH Jr, Jakubowski A, Scheinberg DA, Young CW, et al. Continuous treatment with all-trans retinoic acid causes a progressive reduction in plasma drug concentrations: implications for relapse and retinoid "resistance" in patients with acute promyelocytic leukemia. Blood. 1992;79:299-303.

29. Kerr IG, Lippman ME, Jenkins J, Myers CE. Pharmacology of 13cis-retinoic acid in humans. Cancer Res. 1982;42:2069-73.

30. Goodman GE, Einspahr JG, Alberts DS, Davis TP, Leigh SA, Chen HS, et al. Pharmacokinetics of 13-cis-retinoic acid in patients with advanced cancer. Cancer Res. 1982;42:2087-91.

31. Muindi JR, Roth MD, Wise RA, Connett JE, O'Connor GT, Ramsdell JW, et al. Pharmacokinetics and metabolism of all-transand 13-cis-retinoic acid in pulmonary emphysema patients. J Clin Pharmacol. 2008;48:96-107. doi:10.1177/0091270007309701. 
32. Takitani K, Koh M, Inoue A, Kawakami C, Kuno T, Tamai H. Pharmacokinetics of all-trans retinoic acid in adults and children with acute promyelocytic leukemia. Am J Hematol. 2006;81:720-1. doi:10.1002/ajh.20717.

33. Miller VA, Benedetti FM, Rigas JR, Verret AL, Pfister DG, Straus $\mathrm{D}$, et al. Initial clinical trial of a selective retinoid $\mathrm{X}$ receptor ligand, LGD1069. J Clin Oncol. 1997;15:790-5.

34. Gronemeyer H, Gustafsson JA, Laudet V. Principles for modulation of the nuclear receptor superfamily. Nat Rev Drug Discov. 2004;3:950-64. doi:10.1038/nrd1551.

35. Zusi FC, Lorenzi MV, Vivat-Hannah V. Selective retinoids and rexinoids in cancer therapy and chemoprevention. Drug Discov Today. 2002;7:1165-74. doi:10.1016/S1359-6446(02)02526-6.

36. Dawson MI. Synthetic retinoids and their nuclear receptors. Curr Med Chem Anticancer Agents. 2004;4:199-230. doi:10.2174/ 1568011043352975.

37. White A, Gibson S. ACTH precursors: biological significance and clinical relevance. Clin Endocrinol (Oxf). 1998;48:251-5. doi:10.1046/j.1365-2265.1998.00451.x.

38. Kovalovsky D, Refojo D, Liberman AC, Hochbaum D, Pereda MP, Coso OA, et al. Activation and induction of NUR77/NURR1 in corticotrophs by CRH/cAMP: involvement of calcium, protein kinase A, and MAPK pathways. Mol Endocrinol. 2002;16:163851. doi:10.1210/me.16.7.1638.

39. Therrien M, Drouin J. Pituitary pro-opiomelanocortin gene expression requires synergistic interactions of several regulatory elements. Mol Cell Biol. 1991;11:3492-503.

40. Boutillier AL, Monnier D, Lorang D, Lundblad JR, Roberts JL, Loeffler JP. Corticotropin-releasing hormone stimulates proopiomelanocortin transcription by cFos-dependent and -independent pathways: characterization of an AP1 site in exon 1. Mol Endocrinol. 1995;9:745-55. doi:10.1210/me.9.6.745.

41. Bousquet C, Zatelli MC, Melmed S. Direct regulation of pituitary proopiomelanocortin by STAT3 provides a novel mechanism for immuno-neuroendocrine interfacing. J Clin Invest. 2000; 106:1417-25. doi:10.1172/JCI11182.

42. Maira M, Martens C, Philips A, Drouin J. Heterodimerization between members of the Nur subfamily of orphan nuclear receptors as a novel mechanism for gene activation. Mol Cell Biol. 1999; 19:7549-57.

43. Murphy EP, Conneely OM. Neuroendocrine regulation of the hypothalamic pituitary adrenal axis by the nurr1/nur77 subfamily of nuclear receptors. Mol Endocrinol. 1997;11:39-47. doi:10.1210/ me.11.1.39.

44. Philips A, Lesage S, Gingras R, Maira MH, Gauthier Y, Hugo P, et al. Novel dimeric Nur77 signaling mechanism in endocrine and lymphoid cells. Mol Cell Biol. 1997;17:5946-51.

45. Boutillier AL, Gaiddon C, Lorang D, Roberts JL, Loeffler JP. Transcriptional activation of the proopiomelanocortin gene by cyclic AMP-responsive element binding protein. Pituitary. 1998;1:33-43. doi:10.1023/A:1009966808106.

46. Paez-Pereda M, Kovalovsky D, Hopfner U, Theodoropoulou M, Pagotto U, Uhl E, et al. Retinoic acid prevents experimental Cushing syndrome. J Clin Invest. 2001;108:1123-31.

47. Wu Q, Li Y, Liu R, Agadir A, Lee MO, Liu Y, et al. Modulation of retinoic acid sensitivity in lung cancer cells through dynamic balance of orphan receptors nur77 and COUP-TF and their heterodimerization. EMBO J. 1997;16:1656-69. doi:10.1093/ emboj/16.7.1656.

48. Kliewer SA, Umesono K, Heyman RA, Mangelsdorf DJ, Dyck JA, Evans RM. Retinoid X receptor-COUP-TF interactions modulate retinoic acid signaling. Proc Natl Acad Sci U S A. 1992;89:144852. doi:10.1073/pnas.89.4.1448.

49. Tran P, Zhang XK, Salbert G, Hermann T, Lehmann JM, Pfahl M. COUP orphan receptors are negative regulators of retinoic acid response pathways. Mol Cell Biol. 1992;12:4666-76.

50. Cooney AJ, Leng X, Tsai SY, O’Malley BW, Tsai MJ. Multiple mechanisms of chicken ovalbumin upstream promoter transcription factor-dependent repression of transactivation by the vitamin $\mathrm{D}$, thyroid hormone, and retinoic acid receptors. J Biol Chem. 1993;268:4152-60.

51. Fanjul A, Dawson MI, Hobbs PD, Jong L, Cameron JF, Harlev E, et al. A new class of retinoids with selective inhibition of AP-1 inhibits proliferation. Nature. 1994;372:107-11. doi:10.1038/372107a0.

52. Morita S, Fernandez-Mejia C, Melmed S. Retinoic acid selectively stimulates growth hormone secretion and messenger ribonucleic acid levels in rat pituitary cells. Endocrinology. 1989;124:2052-6.

53. Guibourdenche J, Djakoure C, Porquet D, Pagesy P, RochetteEgly C, Peillon F, et al. Retinoic acid stimulates growth hormone synthesis in human somatotropic adenoma cells: characterization of its nuclear receptors. J Cell Biochem. 1997;65:25-31. doi:10.1002/ (SICI)1097-4644(199704)65:1<25::AID-JCB3>3.0.CO;2-0.

54. Feldman EC, Bruyette DS, Nelson RW, Farver TB. Plasma cortisol response to ketoconazole administration in dogs with hyperadrenocorticism. J Am Vet Med Assoc. 1990;197:71-8.

55. Stalla GK, Stalla J, von WK, Muller OA, Gerzer R, Hollt V, et al. Nitroimidazole derivatives inhibit anterior pituitary cell function apparently by a direct effect on the catalytic subunit of the adenylate cyclase holoenzyme. Endocrinology. 1989;125:699-706.

56. Stalla GK, Stalla J, Huber M, Loeffler JP, Hollt V. von WK, and Muller OA: Ketoconazole inhibits corticotropic cell function in vitro. Endocrinology. 1988;122:618-23.

57. Labeur M, Arzt E, Stalla GK, Paez-Pereda M. New perspectives in the treatment of Cushing's syndrome. Curr Drug Targets Immune Endocr Metabol Disord. 2004;4:335-42. doi:10.2174/1568008043339703.

58. Castillo V, Giacomini D, Paez-Pereda M, Stalla J, Labeur M, Theodoropoulou M, et al. Retinoic acid as a novel medical therapy for Cushing's disease in dogs. Endocrinology. 2006; 147:4438-44. doi:10.1210/en.2006-0414.

59. Tanaka S. Comparative aspects of intracellular proteolytic processing of peptide hormone precursors: studies of proopiomelanocortin processing. Zoolog Sci. 2003;20:1183-98. doi:10.2108/ zsj.20.1183.

60. Lindblad-Toh K, Wade CM, Mikkelsen TS, Karlsson EK, Jaffe DB, Kamal M, et al. Genome sequence, comparative analysis and haplotype structure of the domestic dog. Nature. 2005;438:80319. doi:10.1038/nature 04338 .

61. Scully KM, Rosenfeld MG. Pituitary development: regulatory codes in mammalian organogenesis. Science. 2002;295:2231-5. doi:10.1126/science.1062736.

62. Giacomini D, Paez-Pereda M, Theodoropoulou M, Labeur M, Refojo D, Gerez J, et al. Bone morphogenetic protein-4 inhibits corticotroph tumor cells: involvement in the retinoic acid inhibitory action. Endocrinology. 2006;147:247-56. doi:10.1210/en.2005-0958. 